\title{
Dicer-1, but not Loquacious, is critical for assembly of miRNA-induced silencing complexes
}

\author{
XIANG LIU, ${ }^{1}$ JOSEPH K. PARK, ${ }^{2}$ FENG JIANG, ${ }^{1}$ YING LIU, ${ }^{1}$ DENNIS MCKEARIN, ${ }^{2}$ and QINGHUA LIU ${ }^{1}$ \\ ${ }^{1}$ Department of Biochemistry, University of Texas Southwestern Medical Center, Dallas, Texas 75390, USA \\ ${ }^{2}$ Department of Molecular Biology, University of Texas Southwestern Medical Center, Dallas, Texas 75390, USA
}

\begin{abstract}
Double-stranded RNA-binding proteins (dsRBPs), such as R2D2 and Loquacious (Loqs), function in tandem with Dicer (Dcr) enzymes in RNA interference (RNAi). In Drosophila, Dcr-1/Loqs and Dcr-2/R2D2 complexes generate microRNAs (miRNAs) and small interfering RNAs (siRNAs), respectively. Although R2D2 does not regulate siRNA production, R2D2 and Dcr-2 coordinately bind siRNAs to promote assembly of the siRNA-induced silencing (siRISC) complexes. Conversely, Loqs enhances miRNA production. It is uncertain if Dcr-1 and Loqs facilitate miRNA loading onto the miRISC complexes. Here we used loqs knockout (KO) flies to characterize the physiological functions of Loqs in the miRNA pathway. Northern analysis revealed consistent accumulation of precursor (pre)-miRNAs in $\operatorname{loq} s^{\mathrm{KO}}$ flies. However, the lack of Loqs had differential effects on mature miRNAs: some are diminished, whereas others maintain wild-type levels. Importantly, the data suggest that miRNA production is not the rate-limiting step of the miRNA pathway. We show that Dcr-1, but not Loqs, is critical for assembly of miRISCs by using dcr-1 or loqs null egg extract. Consistent with this, recombinant Dcr-1 could efficiently interact with miRNA duplex in the absence of Loqs. Together, our results indicate that Loqs plays a prominent role in miRNA biogenesis, but is largely dispensable for miRISC assembly. Thus, Loqs and R2D2 represent two distinct functional modes for dsRBPs in the RNAi pathways.
\end{abstract}

Keywords: Dcr-1; Loqs; pre-miRNA; miRNA; miRISC

\section{INTRODUCTION}

RNA interference (RNAi) is a post-transcriptional gene silencing mechanism guided by 21 - to 25-nucleotide(nt) small interfering RNAs (siRNAs) and microRNAs (miRNAs) (Fire et al. 1998; Hannon 2002; Tomari and Zamore 2005; Paroo et al. 2007). The catalytic engine of RNAi consists of two enzymes, Dicer and Argonaute (Ago) (Paroo et al. 2007). Dicer, a multidomain RNase III enzyme, processes long double-stranded (ds)RNA to siRNA or short stemloop precursor (pre)-miRNA to miRNA (Bernstein et al. 2001; Hutvagner et al. 2001). Ago, in conjunction with a siRNA or miRNA, forms the catalytic core of the RNA-induced silencing complexes termed siRISC or miRISC, which directs sequence-specific cleavage and/or translational repression of complementary mRNA (Liu et al. 2004; Song et al. 2004; Rivas et al. 2005).

Reprint requests to: Qinghua Liu, Department of Biochemistry, University of Texas Southwestern Medical Center, Dallas, TX 75390, USA; e-mail Qinghua.Liu@UTsouthwestern.edu; fax (214) 648-8856.

Article published online ahead of print. Article and publication date are at http://www.rnajournal.org/cgi/doi/10.1261/rna.723707.
A typical Dicer is comprised of a DExH helicase domain, a domain of unknown function (DUF)283, a PAZ domain, two RNase III domains, and a dsRNA-binding (dsRBD) domain (Bernstein et al. 2001). Most organisms, including humans, contain a single Dicer that generates both miRNAs and siRNAs. In Drosophila, two Dicers, Dcr-1 and Dcr-2, catalyze miRNA and siRNA production, respectively (Liu et al. 2003; Lee et al. 2004). Biochemical studies establish that Dcr-1 and Dcr-2 enzymes have distinct substrate specificities and ATP requirements (Liu et al. 2003; Jiang et al. 2005). Dcr-1 prefers to process pre-miRNA to miRNA in an ATP-independent manner, whereas Dcr-2 is much more efficient at processing dsRNA and requires ATP hydrolysis for efficient siRNA production (Liu et al. 2003; Jiang et al. 2005).

The Ago family of proteins contains two signature domains, PAZ and PIWI. The PAZ domain of Ago has an oligonucleotide-binding (OB) fold and is believed to bind the 2-nt $3^{\prime}$ overhang of duplex siRNA or miRNA (Lingel et al. 2003; Song et al. 2003; Yan et al. 2003; Ma et al. 2004). The PIWI domain resembles the structure of RNase $\mathrm{H}$ and functions as the slicer of RISC that cleaves the target mRNA (Song et al. 2003, 2004; Liu et al. 2004; 
Rivas et al. 2005). However, not all Ago proteins possess the slicer activity. Among the four human Ago proteins, the slicer activity has only been demonstrated for Ago2 (Liu et al. 2004; Meister et al. 2004). In Drosophila, Agol and Ago2 both possess slicer activity and serve, respectively, as the catalytic core of the miRISC and siRISC complexes (Miyoshi et al. 2005).

It is unclear how siRNA or miRNA is transferred from Dicer to Ago to form the effector RISC complexes. A novel component of RNAi has been revealed by purifying Drosophila siRNA-generating enzyme, which consists of Dcr-2 and R2D2 (Liu et al. 2003). R2D2 is named because of its two dsRBD domains (R2) and association with Dcr-2 (D2). However, R2D2 does not regulate siRNA production (Liu et al. 2003, 2006). Rather, R2D2 cooperates with Dcr-2 to bind siRNA and facilitate siRNA loading onto the effector siRISC complexes (Liu et al. 2003, 2006). Neither Dcr-2 nor R2D2 alone could efficiently interact with duplex siRNA (Liu et al. 2006). Both Dcr-2 and R2D2 are critical components of the RISC loading complex (RLC), the formation of which precedes and is required for RISC activation (Pham et al. 2004; Tomari et al. 2004a; Pham and Sontheimer 2005). R2D2 is a homolog of the previously discovered RDE-4, which also contains two dsRBDs, associates with Dicer and RDE-1 (Ago2 homolog), and is required for RNAi in Caenorhabditis elegans (Tabara et al. 2002) . RDE-4 and R2D2 are two founding members of a growing family of dsRBPs that play important roles in the siRNA and miRNA pathways.

Another dsRBP, Loquacious (Loqs), functions in tandem with Dcr-1 in the Drosophila miRNA pathway (Forstemann et al. 2005; Jiang et al. 2005; Saito et al. 2005). The loqs gene encodes three protein isoforms (PA-PC) through alternative splicing (Forstemann et al. 2005). Only Loqs-PA and Loqs-PB are expressed in fly tissues, and both contain three dsRBD domains. Biochemical fractionation of S2 extract shows that Dcr-1 and Loqs-PB correlate perfectly with the miRNA-generating activity (Jiang et al. 2005). Recombinant Dcr-1 alone is able to process pre-miRNA to miRNA in vitro, whereas Loqs-PB greatly enhances miRNA production by increasing Dcr-1's affinity for pre-miRNA (Jiang et al. 2005). Consistent with this, partial deficiency of Loqs, as a result of RNAi or a hypomorphic mutation, causes accumulation of pre-miRNAs in S2 cells or flies (Forstemann et al. 2005; Jiang et al. 2005; Saito et al. 2005). Thus, Loqs plays a critical role in assisting Dcr-1 to process pre-miRNAs to miRNAs.

To investigate the physiological functions of Loqs, we generate loqs knockout (KO) flies by gene targeting through ends-out homologous recombination (Park et al. 2007). Homozygous loqs ${ }^{\mathrm{KO}}$ flies display severe developmental defects, including embryonic lethality and loss of germline stem cells (GSCs) (Park et al. 2007). Furthermore, mosaic studies indicate that Loqs is intrinsically required for selfrenewal of female GSCs. These phenotypes can be rescued by transgenic expression of Loqs- $\mathrm{PB}$, but not Loqs-PA, suggesting that the Loqs-PB isoform is necessary and sufficient for Drosophila development and the miRNA pathway. In the current study, we performed biochemical analysis of loqs ${ }^{\mathrm{KO}}$ flies to further characterize the functions of Loqs in the miRNA pathway. Our results show that Loqs is required for the production of some miRNAs, but dispensable for others. Moreover, Dcr-1, but not Loqs, is critical for loading miRNA onto the miRISC complexes. Thus, Loqs primarily functions in Drosophila miRNA biogenesis rather than miRISC assembly.

\section{RESULTS AND DISCUSSION}

To determine if Loqs was required for all miRNA biogenesis, we performed Northern blots to systematically examine the levels of 33 out of 78 known miRNAs among wild-type and homozygous loqs ${ }^{\mathrm{KO}}$ flies (Park et al. 2007). Although these miRNAs were chosen based on previous miRNA cloning data from adult flies (Aravin et al. 2003), only half of Northern blots produced detectable signals and clean background. In the majority of cases, we observed significant accumulation of the $\sim 60$ nt pre-miRNAs in loqs ${ }^{\mathrm{KO}}$ flies, indicating a general role of Loqs in assisting Dcr-1 to process pre-miRNA (Fig. 1). By contrast, the lack of Loqs had differential effects on the levels of various mature miRNAs. For example, eight miRNAs (e.g., mir-7 and mir-277) were reduced or eliminated in loqs ${ }^{\mathrm{KO}}$ flies (Fig. 1A). Conversely, eight other miRNAs (e.g., mir-1 and mir-14) showed equivalent levels between wild-type and loqs ${ }^{\mathrm{KO}}$ flies (Fig. 1B). These results indicate that Loqs is required for the production of only a subset of Drosophila miRNAs.

This was a surprising finding because loqs ${ }^{\mathrm{KO}}$ flies not only had a reduced level of Dcr-1 enzyme (data not shown), but also completely lacked Loqs, an enhancer of miRNA production. However, despite these deficiencies in $\operatorname{loqs}^{\mathrm{KO}}$ flies, the remaining Dcr-1 could still produce miRNAs at a sufficient rate to allow almost half of miRNAs to accumulate to wild-type levels (Fig. 1B). Importantly, these data suggest that miRNA production is not the ratelimiting step of the miRNA pathway. It is possible that more miRNAs are produced than can be loaded onto the miRISC complexes, and excess free miRNAs will be rapidly degraded in Drosophila cells.

Northern blotting measures the steady-state levels of miRNAs. In theory, the lack of Loqs may differentially affect the rate of synthesis, miRISC loading, or degradation of different miRNAs in loq ${ }^{\mathrm{KO}}$ flies. For example, some premiRNAs may represent perfect substrates for Dcr-1, and their processing is less dependent or independent of Loqs. Conversely, other pre-miRNAs may represent less optimal substrates or have low affinity for Dcr-1, thereby requiring Loqs for efficient miRNA production. However, our bioinformatic analysis of pre-miRNA sequences has not yielded 
A

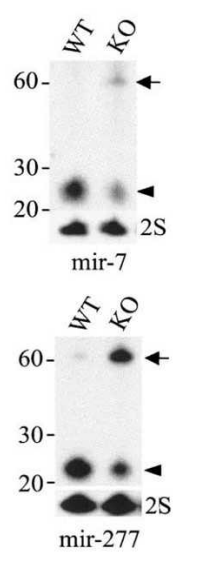

B

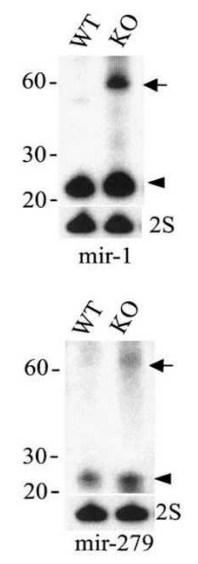

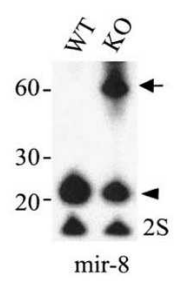
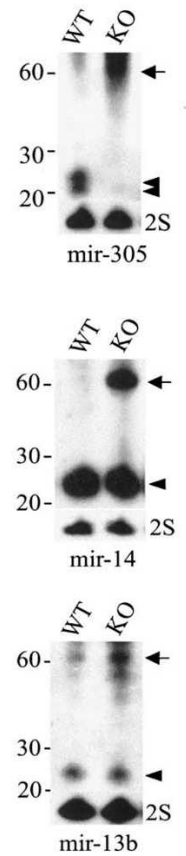
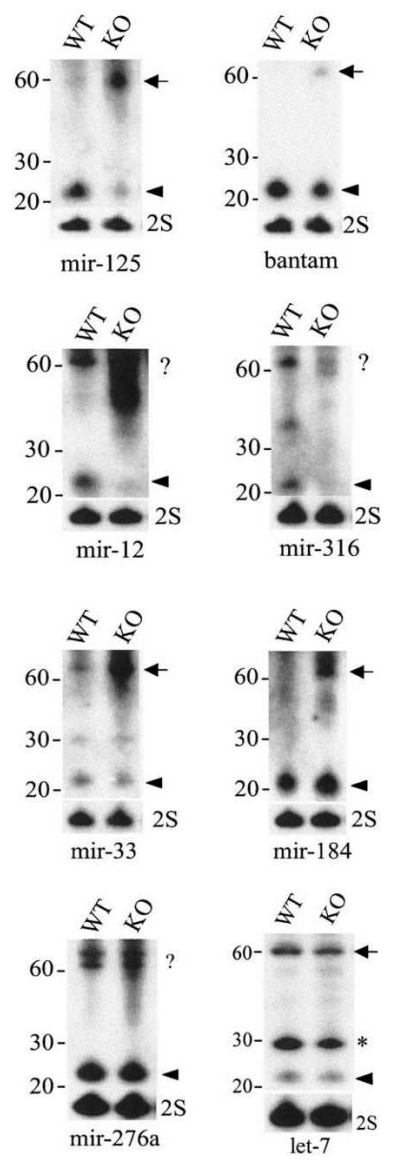

FIGURE 1. Loqs is required for the production of only a subset of miRNAs. (A) Northern blots of eight miRNAs showing pre-miRNA accumulation and miRNA reduction in loqs ${ }^{\mathrm{KO}}$ flies. (B) Northern blots of eight miRNAs showing pre-miRNA accumulation accompanied by wild-type levels of mature miRNAs in $\operatorname{loqs}^{\mathrm{KO}}$ flies. For each Northern blot, size markers are shown on the left. Pre-miRNA and miRNA are marked by arrow and arrowhead, respectively. $2 \mathrm{~S}$ rRNA is used as loading control. Question marks refer to the inability to determine $\sim 60$ nt pre-miRNA.

any obvious features that could distinguish the two miRNA classes. Alternatively, other dsRBPs, such as R2D2, may partially substitute for Loqs in miRNA processing. However, this notion is not supported by our analysis of $r 2 d 2$ loqs double mutant (data not shown). Therefore, future studies are required to uncover the molecular basis of this interesting phenomenon.

Dcr-2 and R2D2 coordinately bind siRNAs to promote efficient assembly of the siRISC complexes (Liu et al. 2003, 2006; Lee et al. 2004; Pham et al. 2004; Tomari et al. 2004b). It will be important to determine if Dcr-1 and Loqs play a similar role in loading miRNAs onto the miRISC complexes. To examine this possibility, we first performed native gel-shift assays to compare the binding of recombinant Dcr-1 proteins to a radiolabeled (Loqs-independent) let7/let ${ }^{\star}$ duplex in the absence or presence of Loqs-PA and Loqs-PB. As shown in Figure 2, recombinant Dcr-1 alone

could efficiently interact with duplex miRNA. While LoqsPA reduced the binding of Dcr-1 to let-7/let* duplex, LoqsPB slightly enhanced it. A similar result was obtained by using a radiolabeled (Loqs-dependent) bantam/ban* duplex. By contrast, only Dcr-2/R2D2 complex, but neither Dcr-2 nor R2D2 alone, can efficiently interact with duplex siRNA (Liu et al. 2006).

To determine if Dcr-1 and Loqs were required for Drosophila miRISC assembly, we generated $d c r-1$ or loqs null extract by using the FLP/ovo ${ }^{\mathrm{D}}$ system (Chou et al. 1993). This mosaic germline system allowed us to bypass the lethality of homozygous $d c r-1^{\mathrm{Q} 1147 \mathrm{X}}$ or loqs $\mathrm{K}^{\mathrm{KO}}$ animals and to produce only mutant eggs that lack maternal and zygotic Dcr-1 or Loqs proteins (see details in Materials and Methods). The $d c r-1^{\mathrm{Q} 1147 \mathrm{X}}$ was considered a null allele because of a nonsense mutation before the catalytic RIII domains (Lee et al. 2004). Western blots confirmed the lack of Dcr-1 or Loqs in $d c r-1$ or loqs null extract (Fig. 3A). The levels of Loqs proteins were reduced in $d c r-1$ null extract and vice versa, suggesting that Dcr-1 and Loqs stabilized each other in vivo.

Next, we performed duplex siRNA and miRNA-initiated RISC (mRNA cleavage) assays using wild-type and loqs or dcr-1 null extracts. Both siRISC and miRISC activity were greatly diminished in $d c r-1$ null extract (Fig. 3B). The miRISC activity was likely Agol mediated since wild-type and ago 2 mutant extracts showed equivalent activities (Fig. 3C). The role of Dcr-1 in siRISC assembly was consistent with previous analysis of the $d c r-1^{\mathrm{Q} 1147 \mathrm{X}}$ mutant (Lee et al. 2004). In contrast, we observed equivalent miRNA- and
A

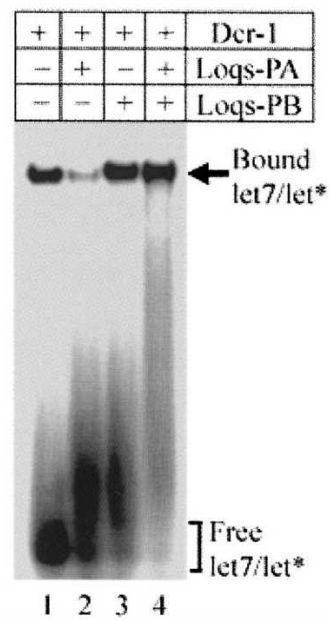

B

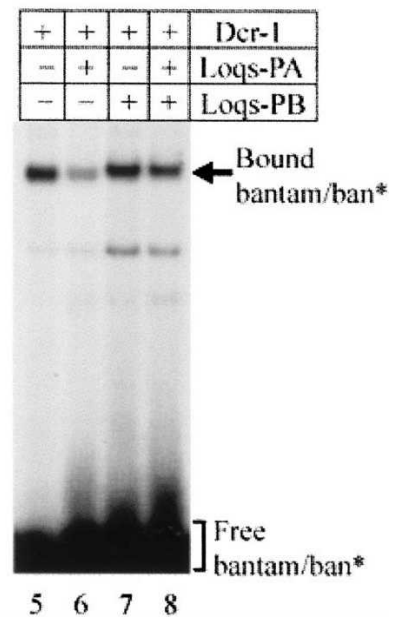

FIGURE 2. Dcr-1 interacts with duplex miRNA in the absence of Loqs. Native gel-shift assays were performed as previously described (Liu et al. 2006) by incubating radiolabeled let-7/let ${ }^{*}(A)$ or bantam/ ban $^{*}(B)$ with 8 pmol recombinant Dcr-1 alone (lanes 1,5) or in combination with 8 pmol Loqs-PA (lanes 2,6), Loqs-PB (lanes 3,7), or Loqs-PA+Loqs-PB (lanes 4,8). 
A

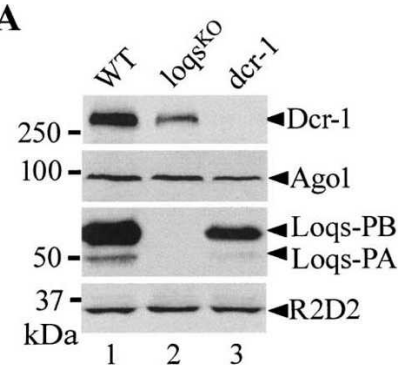

C

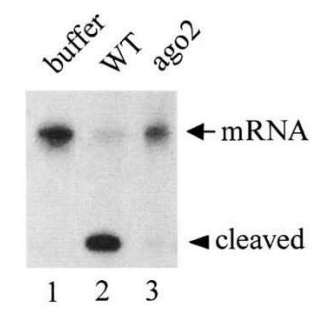

siRNA $\rightarrow$ RISC

D

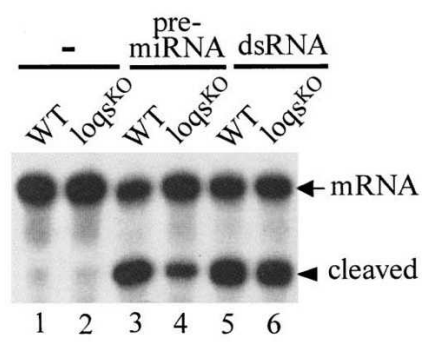

B
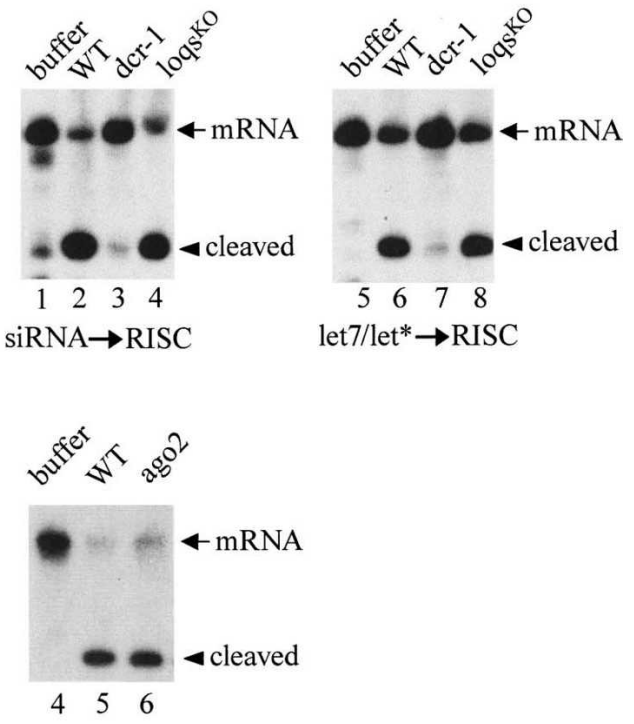

let $7 /$ let* $\rightarrow$ RISC

$\mathbf{E}$

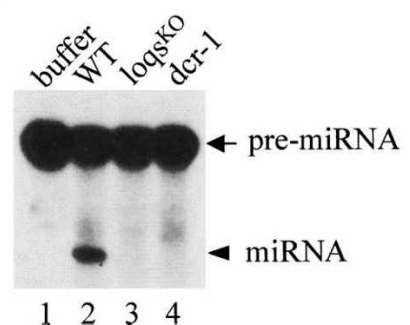

FIGURE 3. Dcr-1, but not Loqs, is critical for assembly of miRISC complexes. (A) Western blots were performed to detect Dcr-1, Ago1, Loqs, and R2D2 in wild-type (WT), loqs ${ }^{\mathrm{KO}}$, or dcr-1 null extract. (B) Duplex siRNA- (lanes 1-4) and miRNA- (lanes 5-8) initiated RISC assays were performed in buffer or $25 \mu \mathrm{g}$ wild-type (WT), loqs ${ }^{\mathrm{KO}}$, or $d c r-1$ null egg extract. (C) Duplex siRNA- (lanes 1-3) and miRNA- (lanes 4-6) initiated RISC assays were performed in buffer or $25 \mu \mathrm{g}$ wild-type (WT) or ago 2 ovary extract. (D) The pre-miRNA- and dsRNAinitiated RISC assays were performed in wild-type (odd lanes) and loqs ${ }^{\mathrm{KO}}$ (even lanes) extracts with water (lanes 1,2), pre-let7 (lanes 3,4), or dsRNA (lanes 5,6) as triggers. $(E)$ The premiRNA-processing assays were performed in buffer or $10 \mu \mathrm{g}$ of wild-type, loqs ${ }^{\mathrm{KO}}$, or $d c r-1$ null extract (Jiang et al. 2005).

siRNA-initiated RISC activities between wild-type and loqs null extracts (Fig. 3B). These results indicate that Dcr-1, but not Loqs, is critical for Drosophila miRISC assembly.

Interestingly, the RISC assembly defect of $d c r-1$ null extract could not be rescued by recombinant Dcr-1 or Dcr$1 /$ Loqs complex (data not shown). It is possible that the lack of Dcr-1 causes reduction in other critical RNAi components. Alternatively, the $d c r-1$ mutant may fail to produce a miRNA that normally represses an inhibitor of RNAi. Thus, it is currently unclear if Dcr-1 is directly or indirectly involved in miRISC or siRISC assembly.

Although loqs null extract was defective for pre-miRNAinitiated RISC activity, the magnitude of the effect (23 -fold) was significantly less than the defect in pre-miRNAprocessing activity ( $>10$-fold) (Fig. 3D,E). Thus, the primary defect of loqs null extract is likely in pre-miRNA processing rather than miRISC assembly. Moreover, this result supports the idea that miRNA production is not the rate-limiting step of Drosophila miRNA pathway.

We further examined in vivo miRNA loading by using a monoclonal antiAgol antibody to immunoprecipitate (IP) the endogenous miRISC complexes followed by Northern blots to measure the abundance of miRNAs (Miyoshi et al. 2005). While the level of (Loqsindependent) mir-14 was equivalent in total RNAs of wild-type (WT) and loqs ${ }^{\mathrm{KO}}$ eggs, the Agol-associated mir-14 in loqs ${ }^{\mathrm{KO}}$ extract was $83 \%$ of that from WT control (Fig. 4A). On the other hand, the level of (Loqs-dependent) bantam was reduced $(60 \%$ of WT) in loqs ${ }^{\mathrm{KO}}$ eggs, and a similar reduction was observed ( $43 \%$ of WT) for Ago1asssociated bantam miRNA (Fig. 4B). These results suggest that Loqs is largely dispensable for miRISC assembly in vivo. It is likely that the small decrease in miRNA loading is due to the reduction of Dcr-1 protein in loqs ${ }^{\mathrm{KO}}$ flies (Fig. 3A).

Recent studies have shown that Dcr-1 and Loqs are both required for embryonic viability and self-renewal of Drosophila ovarian GSCs (Lee et al. 2004; Jin and Xie 2007; Park et al. 2007). However, $d c r-1^{-1-}$ GSCs, but not $\operatorname{loqs}^{-1-}$ GSCs, also display a cell cycle defect at G1/S transition (Hatfield et al. 2005; Park et al. 2007). Additionally, Dcr-1, but not Loqs, is required for somatic stem cell (SSC) maintenance (Jin and Xie 2007; Park et al. 2007). These results suggest that the $d c r-1$ mutant phenotype is more severe than that of loqs ${ }^{\mathrm{KO}}$ flies. Consistent with this, we showed that only a subset of miRNAs was diminished, whereas others maintained wild-type levels in loqs ${ }^{\mathrm{KO}}$ animals (Fig. 1). By contrast, we could not detect mir-14 or bantam in $d c r-1$ null eggs by Northern blotting (Fig. 4), suggesting that Dcr-1 was likely responsible for all miRNA biogenesis. Furthermore, our studies showed that Dcr-1, but not Loqs, was critical for loading miRNA onto the miRISC complexes. Together, these results provide the biochemical basis for the phenotypic differences between $d c r-1$ and loqs mutant flies.

Both R2D2 and Loqs belong to a growing family of dsRBPs that function in tandem with Dicer enzymes in the siRNA and/or miRNA pathways (Paroo et al. 2007). Previous and current studies present two different modes of 
A

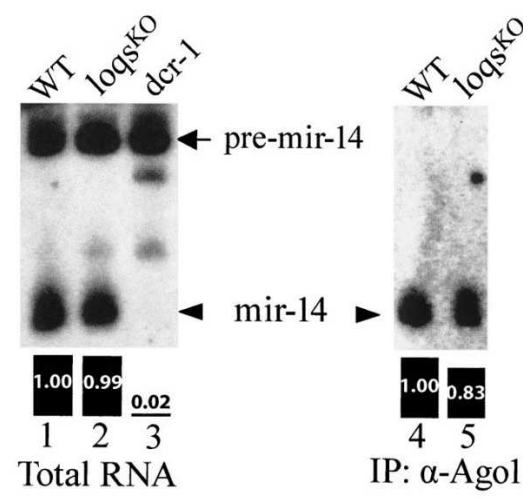

B

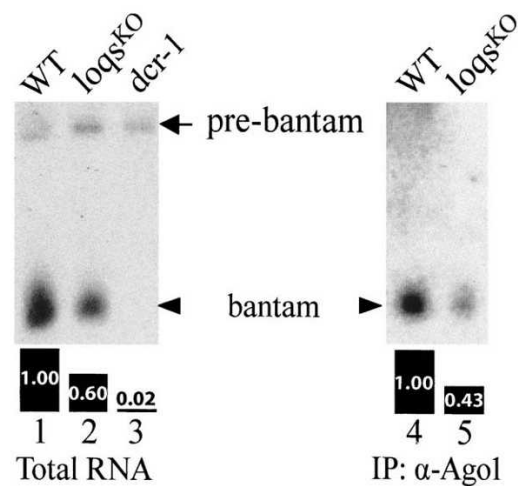

FIGURE 4. Loqs is largely dispensable for miRISC assembly in vivo. The mir-14 $(A)$ and bantam $(B)$ Northern blots of total RNA isolated from wild-type (WT), loqs ${ }^{\mathrm{KO}}$, and $d c r-1$ null eggs (lanes 1-3), and miRNAs extracted from Ago1 IPs from wild-type and loqs ${ }^{\mathrm{KO}}$ egg extracts (lanes 4,5). The bar graphs beneath indicate the quantification of the relative levels of mature miRNAs.

functions for dsRBPs: (1) R2D2 does not regulate siRNA production, but is required for loading siRNA onto the siRISC complexes (Liu et al. 2003, 2006; Tomari et al. 2004b). (2) Loqs plays a prominent role in miRNA biogenesis, but is largely dispensable for assembly of the miRISC complexes (Forstemann et al. 2005; Jiang et al. 2005; Saito et al. 2005). These studies will have important implications for understanding the functions of dsRBPs in other RNAi model systems.

\section{MATERIALS AND METHODS}

\section{Northern blot}

Total RNA was isolated from wild-type and homozygous loqs ${ }^{\mathrm{KO}}$ unfertilized eggs or young adult flies by using TRIzol (Invitrogen), resolved by $12 \%$ denaturing ( $7 \mathrm{M}$ urea) polyacrylamide gels, and transferred onto Zeta-probe membrane (Bio-Rad). While $30 \mu \mathrm{g}$ total RNA from whole flies were loaded per lane (Fig. 1), $100 \mu \mathrm{g}$ of total RNA were used for unfertilized eggs (Fig. 4). The Agol IPs were performed essentially as previously described (Miyoshi et al. 2005). In brief, $5 \mathrm{mg}$ of wild-type and loqs null extract were incubated with $10 \mu \mathrm{L}$ of anti-Agol monoclonal antibody for $2 \mathrm{~h}$ at $4^{\circ} \mathrm{C}$ followed by addition of $10 \mu \mathrm{L}$ of Protein A beads and rotating at $4^{\circ} \mathrm{C}$ for $4 \mathrm{~h}$. After washing five times with the IP-wash buffer (see above), $200 \mu \mathrm{L}$ of buffer A and $800 \mu \mathrm{L}$ of TRIzol were added to extract the miRNA associated with Ago1. Northern hybridization was carried out at $40^{\circ} \mathrm{C}$ in $0.2 \mathrm{M}$ sodium phosphate $(\mathrm{pH} 7.0)$ and $7 \%$ SDS for $16 \mathrm{~h}$ followed by two washes in $2 \times$ SSC and $0.1 \%$ SDS, once at room temperature for $5 \mathrm{~min}$ and again at $40^{\circ} \mathrm{C}$ for 20 min. All probes were synthetic 21-nt RNA oligos (IDT) that were complementary to miRNA sequences provided by miRBase (http://microrna.sanger.ac.uk/) and were $5^{\prime}$-end labeled with $\gamma-{ }^{32} \mathrm{P}$ ATP by T4 polynucleotide kinase (NEB). A DNA oligo, 5'-TACAACCCTCAACCATATGTAGTCCAAGCA-3', was used for probing $2 \mathrm{~S}$ rRNA as loading control.

\section{Generation of loqs or dcr-1 null egg extracts}

To generate loqs null egg extract, we created mosaic germlines by crossing virgin female flies of yw [hsFLP]; loqs ${ }^{\mathrm{KO}}$ [FRT] 40A/CyO (Park et al. 2007) with male flies of ovo ${ }^{\text {D1-18 }}\left[\right.$ FRT] $40 \mathrm{~A} / \mathrm{MS}(2) \mathrm{M}^{1}$ $\mathrm{Sp} / \mathrm{CyO}$ (BL\# 2121). The parents were flipped into fresh bottles every 3-4 $\mathrm{d}$ and the progenies heat shocked in a $38^{\circ} \mathrm{C}$ water bath for $1.5 \mathrm{~h}$ /day for two consecutive days. After eclosing, we sorted $\mathrm{F} 1$ virgin mosaic females with the genotype yw [hsFLP]/+; loqs ${ }^{\mathrm{KO}}$ [FRT]40A/ovo ${ }^{\text {D1-18 }}$ [FRT]40A. Similarly, we used virgin female flies of yw[hsFLP]; [FRT]40A/Cyo to generate wild-type control eggs. For $d c r-1$ null extract, we crossed virgin female flies of yw [hsFLP]; [FRT] $82 \mathrm{~B} d c r-1^{\mathrm{Q} 1147 \mathrm{X}} / \mathrm{TM} 3$ (Lee et al. 2004) and male flies of $\mathrm{w}^{*}$; [FRT] $82 \mathrm{~B}$ ovo ${ }^{\mathrm{D} 1-18} / \beta \mathrm{Tub} 85 \mathrm{D}^{\mathrm{D}} / \mathrm{TM} 3$ (BL\# 2149). We sorted $\mathrm{F} 1$ virgin mosaic females with the genotype $y \mathrm{w}[\mathrm{hsFLP}] / \mathrm{w}^{\star}$; [FRT] 82B $d c r-1^{\mathrm{Q} 1147 \mathrm{X}} /[\mathrm{FRT}] 82 \mathrm{~B}$ ovo ${ }^{\mathrm{D} 1-18}$.

Because ovo ${ }^{\mathrm{D} 1-18}$ is a dominant sterile marker, mature oocytes can only develop from GSCs that lack ovo ${ }^{\mathrm{D}}$ and are homozygous for $\operatorname{loqs}{ }^{\mathrm{KO}}$ or $d c r-1$ Q1147X mutation, which are generated by the Flipase (FLP)/FRT-mediated mitotic recombination. Thus, the F1 virgin mosaic females could produce $100 \%$ of $\operatorname{loqs}^{\mathrm{KO}}$ or $d c r-1$ Q1147X mutant eggs. Only a small time window allowed for mutant egg collection because Dcr-1 and Loqs were both required for self-renewal of GSCs (Jin and Xie 2007; Park et al. 2007). We optimized this procedure to generate thousands of F1 mosaic virgin females and collect loqs or $d c r-1$ mutant eggs every $24 \mathrm{~h}$ on apple juice plates with wet yeast paste.

We treated unfertilized eggs with $50 \%$ bleach for $2 \mathrm{~min}$ followed by washing twice with DEPC-treated water and once with buffer A (10 mM KOAc, $10 \mathrm{mM}$ HEPES at pH 7.4, $10 \mathrm{mM}$ $\mathrm{Mg}(\mathrm{OAc})_{2}$, and $\left.5 \mathrm{mM} \mathrm{DTT}\right)$. Subsequently, we added to dechorinated eggs two volumes of buffer A that were freshly supplemented with protease inhibitors (Roche) and SuperRNase inhibitor (0.5 unit/ $\mu \mathrm{L}$ ) (Ambion). After sitting on ice for $15 \mathrm{~min}$, the eggs were dounced 30 times followed by centrifugation at 13,000 rpm for $20 \mathrm{~min}$ at $4^{\circ} \mathrm{C}$. We saved the supernatant as $d c r-1$ or loqs null extracts in $\mathrm{a}-80^{\circ} \mathrm{C}$ freezer.

\section{In vitro biochemical assays}

The miRNA gel-shift assays were conducted as previously described (Liu et al. 2006). The let-7/let* miRNA (Dharmacon) were radiolabeled with $\gamma^{-32} \mathrm{P}$ at the $5^{\prime}$ end by T4 polynucleotide kinase. All in vitro RISC assays were performed as described (Liu et al. 2003, 2006). The mRNA substrate was radiolabeled at the 
5' G cap by guanylyl transferase (Ambion) followed by PAGE purification. In brief, $25,000 \mathrm{cpm}$ radiolabeled mRNA was incubated with fly egg extracts for $1 \mathrm{~h}$ at $30^{\circ} \mathrm{C}$ in $1 \times$ buffer 12 (100 mM KOAc, $10 \mathrm{mM}$ HEPES at $\mathrm{pH} 7.4,2 \mathrm{mM} \mathrm{Mg}(\mathrm{OAc})_{2}$, and $5 \mathrm{mM}$ DTT) in the presence of an ATP-regenerating system (1 mM ATP, $30 \mathrm{mM}$ creatine phosphate [Fluka], and 30 unit creatine phosphokinase [Sigma]). Both pre-let-7 and dsRNA (130 bp) triggers were used at $250 \mathrm{nM}$ final concentration. Duplex let-7 siRNA and let-7/let* miRNA were used at $25 \mathrm{nM}$ and $100 \mathrm{nM}$ final concentration, respectively.

\section{ACKNOWLEDGMENTS}

We thank Drs. Richard Carthew, Mikiko Siomi, and Haru Siomi for reagents, Rosanna Addison and Inga Denman for technical assistance, and Drs. Yi Liu and Kristen Lynch for discussion and critical comments on the manuscript. J.K.P. thanks the University of Texas Southwestern Medical Scientist Training Program for advice and support. Q.L. is a W.A. "Tex" Moncrief Jr. Scholar in Medical Research and a Damon Runyon Scholar, supported by the Damon Runyon Cancer Research Foundation (DRS-43). The work is also supported by a Welch grant (I-1608) and National Institute of Health grants awarded to Q.L. (GM078163) and to D.M.M. (GM045820).

Received July 9, 2007; accepted August 29, 2007.

\section{REFERENCES}

Aravin, A.A., Lagos-Quintana, M., Yalcin, A., Zavolan, M., Marks, D., Snyder, B., Gaasterland, T., Meyer, J., and Tuschl, T. 2003. The small RNA profile during Drosophila melanogaster development. Dev. Cell 5: 337-350.

Bernstein, E., Caudy, A.A., Hammond, S.M., and Hannon, G.J. 2001. Role for a bidentate ribonuclease in the initiation step of RNA interference. Nature 409: 363-366.

Chou, T.B., Noll, E., and Perrimon, N. 1993. Autosomal P[ovo $\left.{ }^{D 1}\right]$ dominant female-sterile insertions in Drosophila and their use in generating germ-line chimeras. Development 119: 1359-1369.

Fire, A., Xu, S., Montgomery, M.K., Kostas, S.A., Driver, S.E., and Mello, C.C. 1998. Potent and specific genetic interference by double-stranded RNA in Caenorhabditis elegans. Nature 391: 806-811.

Forstemann, K., Tomari, Y., Du, T., Vagin, V.V., Denli, A.M., Bratu, D.P., Klattenhoff, C., Theurkauf, W.E., and Zamore, P.D. 2005. Normal microRNA maturation and germ-line stem cell maintenance requires Loquacious, a double-stranded RNAbinding domain protein. PLoS Biol. 3: e236. doi: 10.1371/journal. pbio.0030236.

Hannon, G.J. 2002. RNA interference. Nature 418: 244-251.

Hatfield, S.D., Shcherbata, H.R., Fischer, K.A., Nakahara, K., Carthew, R.W., and Ruohola-Baker, H. 2005. Stem cell division is regulated by the microRNA pathway. Nature 435: 974-978.

Hutvagner, G., McLachlan, J., Pasquinelli, A.E., Balint, E., Tuschl, T., and Zamore, P.D. 2001. A cellular function for the RNAinterference enzyme Dicer in the maturation of the let-7 small temporal RNA. Science 293: 834-838.

Jiang, F., Ye, X., Liu, X., Fincher, L., McKearin, D., and Liu, Q. 2005. Dicer-1 and R3D1-L catalyze microRNA maturation in Drosophila. Genes \& Dev. 19: 1674-1679.

Jin, Z. and Xie, T. 2007. Dcr-1 maintains Drosophila ovarian stem cells. Curr. Biol. 17: 539-544.
Lee, Y.S., Nakahara, K., Pham, J.W., Kim, K., He, Z., Sontheimer, E.J., and Carthew, R.W. 2004. Distinct roles for Drosophila Dicer-1 and Dicer-2 in the siRNA/miRNA silencing pathways. Cell 117: 69-81.

Lingel, A., Simon, B., Izaurralde, E., and Sattler, M. 2003. Structure and nucleic-acid binding of the Drosophila Argonaute 2 PAZ domain. Nature 426: 465-469.

Liu, Q., Rand, T.A., Kalidas, S., Du, F., Kim, H.E., Smith, D.P., and Wang, X. 2003. R2D2, a bridge between the initiation and effector steps of the Drosophila RNAi pathway. Science 301: 1921-1925.

Liu, J., Carmell, M.A., Rivas, F.V., Marsden, C.G., Thomson, J.M., Song, J.J., Hammond, S.M., Joshua-Tor, L., and Hannon, G.J. 2004. Argonaute2 is the catalytic engine of mammalian RNAi. Science 305: 1437-1441.

Liu, X., Jiang, F., Kalidas, S., Smith, D., and Liu, Q. 2006. Dicer-2 and R2D2 coordinately bind siRNA to promote assembly of the siRISC complexes. RNA 12: 1514-1520.

Ma, J.B., Ye, K., and Patel, D.J. 2004. Structural basis for overhangspecific small interfering RNA recognition by the PAZ domain. Nature 429: 318-322.

Meister, G., Landthaler, M., Patkaniowska, A., Dorsett, Y., Teng, G., and Tuschl, T. 2004. Human Argonaute2 mediates RNA cleavage targeted by miRNAs and siRNAs. Mol. Cell 15: 185-197.

Miyoshi, K., Tsukumo, H., Nagami, T., Siomi, H., and Siomi, M.C. 2005. Slicer function of Drosophila Argonautes and its involvement in RISC formation. Genes \& Dev. 19: 2837-2848.

Park, J.K., Liu, X., Strauss, T.J., McKearin, D.M., and Liu, Q. 2007. The miRNA pathway intrinsically controls self-renewal of Drosophila germline stem cells. Curr. Biol. 17: 533-538.

Paroo, Z., Liu, Q., and Wang, X. 2007. Biochemical mechanisms of the RNA-induced silencing complex. Cell Res. 17: 187-194.

Pham, J.W. and Sontheimer, E.J. 2005. Molecular requirements for RNA-induced silencing complex assembly in the Drosophila RNA interference pathway. J. Biol. Chem. 280: 39278-39283.

Pham, J.W., Pellino, J.L., Lee, Y.S., Carthew, R.W., and Sontheimer, E.J. 2004. A Dicer-2-dependent 80s complex cleaves targeted mRNAs during RNAi in Drosophila. Cell 117: 83-94.

Rivas, F.V., Tolia, N.H., Song, J.J., Aragon, J.P., Liu, J., Hannon, G.J., and Joshua-Tor, L. 2005. Purified Argonaute2 and an siRNA form recombinant human RISC. Nat. Struct. Mol. Biol. 12: 340349.

Saito, K., Ishizuka, A., Siomi, H., and Siomi, M.C. 2005. Processing of pre-microRNAs by the Dicer-1-Loquacious complex in Drosophila cells. PLoS Biol. 3: e235. doi: 10.1371/journal.pbio.0030235.

Song, J.J., Liu, J., Tolia, N.H., Schneiderman, J., Smith, S.K., Martienssen, R.A., Hannon, G.J., and Joshua-Tor, L. 2003. The crystal structure of the Argonaute2 PAZ domain reveals an RNA binding motif in RNAi effector complexes. Nat. Struct. Biol. 10: 1026-1032.

Song, J.J., Smith, S.K., Hannon, G.J., and Joshua-Tor, L. 2004. Crystal structure of Argonaute and its implications for RISC slicer activity. Science 305: 1434-1437.

Tabara, H., Yigit, E., Siomi, H., and Mello, C.C. 2002. The dsRNA binding protein RDE-4 interacts with RDE-1, DCR-1, and a DExH-box helicase to direct RNAi in C. elegans. Cell 109: 861-871.

Tomari, Y. and Zamore, P.D. 2005. Perspective: Machines for RNAi. Genes \& Dev. 19: 517-529.

Tomari, Y., Du, T., Haley, B., Schwarz, D.S., Bennett, R., Cook, H.A., Koppetsch, B.S., Theurkauf, W.E., and Zamore, P.D. 2004a. RISC assembly defects in the Drosophila RNAi mutant armitage. Cell 116: $831-841$.

Tomari, Y., Matranga, C., Haley, B., Martinez, N., and Zamore, P.D. 2004b. A protein sensor for siRNA asymmetry. Science 306: 13771380.

Yan, K.S., Yan, S., Farooq, A., Han, A., Zeng, L., and Zhou, M.M. 2003. Structure and conserved RNA binding of the PAZ domain. Nature 426: $468-474$. 

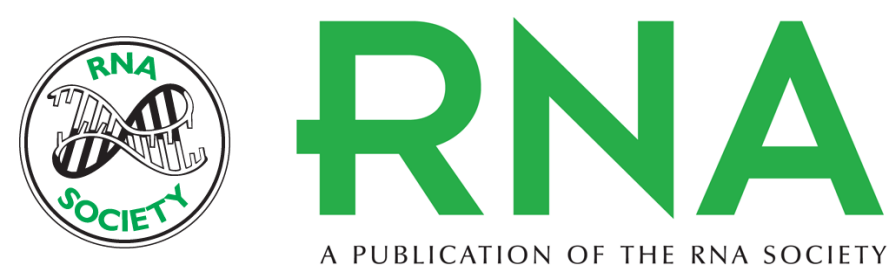

\section{Dicer-1, but not Loquacious, is critical for assembly of miRNA-induced silencing complexes}

Xiang Liu, Joseph K. Park, Feng Jiang, et al.

RNA 2007 13: 2324-2329

References This article cites 31 articles, 11 of which can be accessed free at:

http://rnajournal.cshlp.org/content/13/12/2324.full.html\#ref-list-1

\section{License}

Email Alerting Receive free email alerts when new articles cite this article - sign up in the box at the Service top right corner of the article or click here. 